\title{
Political Economy of Municipal Solid Waste Management in Urban Areas of Developing Countries and Framework of Capacity Development Support
}

[Mitsuo Yoshida]

\begin{abstract}
This paper discusses the municipal solid waste management problem which occurs in urban areas of developing countries, with special regard to the political economy of the following topics: urbanization and waste problem; waste problem and needs for municipal solid waste management; and financial issue of municipal solid waste management. For the solution of the municipal solid waste problem in urban areas it is necessary to transform the system to more effective and efficient with financial viability. Capacity Development (CD) of entire society of city is required and $\mathrm{CD}$ support framework is proposed.
\end{abstract}

Keywords- Urbanization, Solid Waste Management, Political Economy, Informal Sector, Capacity Development

\section{Introduction}

Proper management of municipal solid waste is one of the biggest social and environmental issues in developing countries, particularly at rapidly growing urban areas. It is almost always in the top five of the most challenging problems for city managers in developing countries [1]. Due to large amount of waste generation, traditional waste management system is malfunctioned particularly in highly populated urban areas, where waste collection service cannot be sufficiently provided by municipality (or local authority) and the waste collection rate against the total amount of waste generated is low. It is sometimes difficult for local authority of developing countries to establish sustainable municipal solid waste management (MSWM) which provides adequate level of service to the public, due to mainly financial shortage.

Financial viability in MSWM is a major issue for most municipalities in developing countries, where the cost for MSWM service takes a significant proportion of the total budget of the municipality, ranging from 3 to $15 \%$ [1]. The costs increase by the adoption of more strict environmental protection measures. The cost would increase, because waste quantities are going to increase significantly, various waste types generated by modern life style require much more complicated treatment and more staff, and equipment and facilities will be required to adequately manage them [2]. Thus, it is urgent that municipalities find ways to recover required MSWM costs in order to keep its environment and sustainability.

Mitsuo Yoshida

Japan International Cooperation Agency (JICA)

Tokyo, Japan

Department of International Studies, Graduate School of Frontier Sciences, The University of Tokyo, Kashiwa, Japan
In this paper the author discuss mainly financial problems of MSWM in urban area of developing countries from the view of political economy, and international cooperation framework of capacity development support in MSWM to developing countries.

\section{Urbanization, Economic Growth and Urban Problem}

\section{A. Urbanization and Economic Growth}

According to the United Nation's study [3], 54\% of world's population resides in urban areas. It is widely believed that the urban areas create wealth, generate employment, and promote economic growth by the forces of agglomeration and industrialization. And in fact, there is a positive correlation between urbanization and economic growth, where urbanization level can be correlated with level of national income on the basis of the results of crosscountry analysis [4] [5] [6] [7] [8]. Successful economy in the urbanized area will attract investment, create job opportunities, and encourage consumption.

The concentration of population is caused by the migration of rural people into the city who expect higher income in urban area than that in rural area, which is known as Harris-Todaro model [9]. The migration and increase of agglomeration give a further mechanism of urban growth. The benefits of urbanization are defined as "agglomeration economies" (or "economies of agglomeration"), which relates to the idea of economies of scale and network effects [10] [11].

It is noted that above-mentioned economic growth accompanied with urbanization is observed in most East Asian cities [5], but in Sub-Saharan African cities urbanization often occurred without economic growth [12]. Factors generate differences in economic growth vs. urbanization are considered to be the following: income structure, education, rural-urban wage differentials, ethnic tensions, and civil disturbances. The urbanization in Asia has been driven mostly by industrialization and a creation of job opportunities in urban areas, whereas urbanization in Africa seems to be more the result of population pressure, civil conflict, and changing political regimes as well as ethnic tensions and a momentum effect [4] [12].

Informal sector appears to provide a significant source of income for urban migrants in Africa (more than 55\% share of GDP according to [13]), which is probably another reason that urbanization does not correspond to economic growth in official economic statistics.". 


\section{B. Urban Problem - Negative Impacts of Urbanization}

The growth of urban areas also leads to traffic congestion, overcrowding population, water and air pollution. Such environmental degradation problems in urban areas are apparently caused by rapid increase of population, industrialization, and growth of economic activities. The urban environment, such as living clean environment, air, soil, water, amenity, etc., possesses a nature of less excludable and high subtractable "commonpool resource" (Table 1).

A common-pool resource typically consists of "stock", while providing a limited quantity of extractable fringe units ("flow"). Although the stock is to be protected in order to allow for its continuous exploitation, the fringe units can be harvested or consumed [14]. That is the main reason of environmental degradation under rapid urbanization (see Table 1)

The urban environment is a kind of common-pool resources for inhabitants in urban areas, and if the urbanization exceed, more public goods, such as air, water and soil, become fragile common-pool resources, which inhibits sustainable development.

In addition to the environmental degradation, urbanization is associated with the formation of large and rapidly growing slum populations in and around big cities [4]. According to UN-Habitat, one third of the urban population in developing countries lived in slums. The slum populations are composed of informal dwellers and socially vulnerable with social exclusion, which is negative side of economic growth of urban areas. The slum populations are generally not fully recognized by city authorities, and have no public service or support from them.

Thus, rapid urbanization is associated with various environmental degradation and social problems, which essentially inhibit social progress and sustainable economic development. It indicates the presence of "low-quality urbanization", i.e., an agglomeration without appropriate economic and social structures to control the negative impacts [15]. The negative phenomena associated by urbanization are collectively named as "urban problem", which is typical demerit of agglomeration [16].

Table 1: The urban environment shows the nature of "common-pool resources". Common-pool resources are characterized as resources for which the exclusion of users is difficult (referred to as "exclusion"), and the use of such a resource by one user decreases resource benefits for other users (referred to as "subtractability"). The terminology in the table is adopted from the definition given by Ostrom [17].

\begin{tabular}{|c|c|c|c|}
\cline { 3 - 4 } \multicolumn{2}{c|}{} & \multicolumn{2}{c|}{ Subtractability } \\
\cline { 3 - 4 } \multicolumn{2}{c|}{ Exclusion } & Low & High \\
\cline { 3 - 4 } & Difficult & $\begin{array}{c}\text { Public } \\
\text { goods }\end{array}$ & $\begin{array}{c}\text { Common-pool } \\
\text { resources }\end{array}$ \\
\cline { 2 - 4 } & Easy & Toll goods & Private goods \\
\hline
\end{tabular}

Between positive and negative effects of urbanization, there might be a best degree of urban concentration, in terms of maximizing productivity. The best degree of urban concentration varies with the level of development and other external condition, and over or under-concentration can be very costly in terms of productivity growth [6]. Thus, urban planning is very important for realizing economic and social development in urban areas, where well control of "urban problems" and good governance for "common-pool resources" are the key for municipalities or urban authorities.

\section{Control of Urban Problem}

The urbanization engenders two effects, "agglomeration economics" and "demerit of agglomeration" (Figure 1). The former creates economic growth and profits, but the latter results in environmental degradation and social problems. In order to protect the environment and human life in the urban areas, it is necessary to establish effective management system for the urban environment, in particular the common-pool resources (i.e., "governing the commons" [14]). The management system includes various public services, such as solid waste management, wastewater treatment, etc., for protecting urban environment and public sanitation. Without such services, the urban environment deteriorated and become inhibiting factors to the agglomeration economies (Figure 1).

Of course, necessary financial mechanism to sustain the system operation is required. The costs for environmental management, protection, and control, have to be incurred by the profits of agglomeration economies (Figure 1).

\section{Waste Problem as an Urban Problem}

\section{A. Characteristics of Waste Problem in Urban Areas}

Waste problem is one of the most frequently recognized urban problems. There are two aspects of the waste problem: quality and quantity sides. The quantity side of waste problem is rapid increase of waste amount in the cities and disposal sites. Accumulation of solid waste without collection in residential areas, waste littering along urban streets, and inadequate waste dumping nearby urban zones, which cause public health damage, amenity loss, and environmental degradation. The quality side of waste problem is rapid increase of waste types difficult to be treated. Under modern life style and mass consumption economy, artificially-synthesized materials such as plastics and chemical compounds remarkably flow in the waste stream. Toxic substances are often contained in the flow, which need specific treatments for preventing hazard. In fact, all those necessary waste treatments associated with the urbanization require additional costs for MSWM.

Who should pay the costs for countermeasures? 
Proc. of The Fifth Intl. Conf. On Advances in Applied Science and Environmental Technology - ASET 2016 Copyright @ Institute of Research Engineers and Doctors, USA .All rights reserved.

ISBN: 978-1-63248-106-1 doi: 10.15224/ 978-1-63248-106-1-34

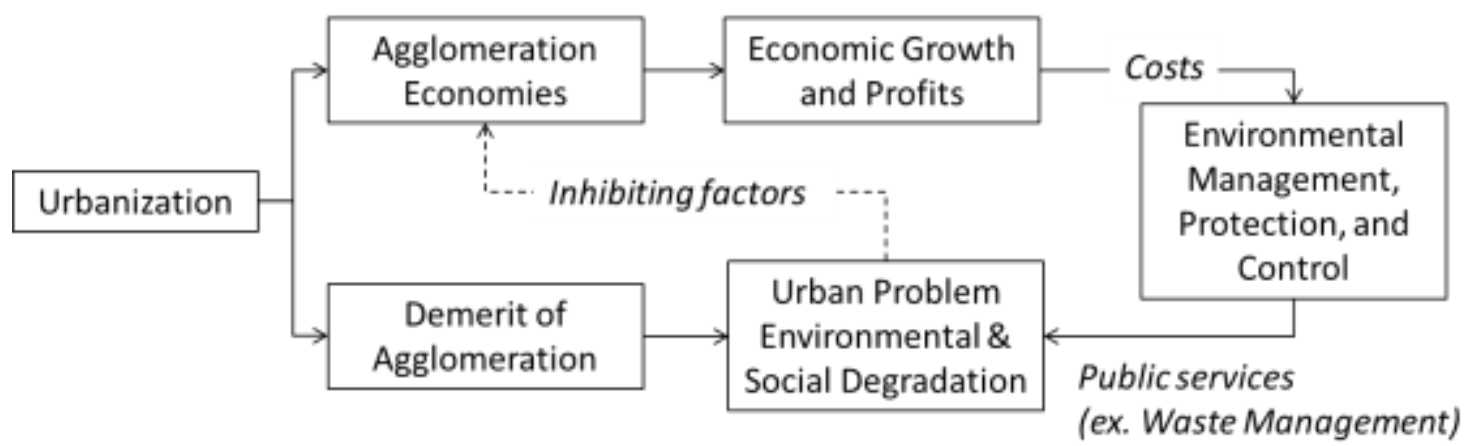

Figure 1: Measure to be taken against urban environmental problem caused by urbanization. The profit by agglomeration economies is required to utilize for the costs against the urban problem.

\section{B. Financial Issues of MSWM in Urban Areas}

Establishing proper municipal solid waste management (MSWM) system including waste collection, transportation, treatment, and disposal, is required to solve the waste problem as mentioned above, which is generally the responsibility of municipalities or other local authorities. It is necessary for municipality to organize MSWM department or public implementation agency which provides MSWM service to citizens and community. In order to establish MSWM system and implement the MSWM service, sustainable financial management, in particular collecting revenue is required.

Financial aspects of municipal solid waste management (MSWM) include: (i) budgeting and cost accounting systems, (ii) resource mobilization for capital investments, (iii) cost recovery and operational financing, and (iv) cost reduction and control [18]. However, in general, the financial information from municipalities in developing countries, such as overall costs and revenues, is not always sufficient and real cost and budgeting mechanisms are unclear due to fragmented organizations [1]. The costs of providing MSWM services are commonly underestimated due to a lack of holistic view of real waste streams. Financial monitoring and continuous analyses of the financial data are absolutely essential to understand the financial flows. Therefore, at first, realistic understanding of waste streams and financial information on waste management are required.

Establishing sustainable financial management, the following points have to be considered: General idea for SWM finance is: (i) the cost of SWM generated by industries and commercial sector (=beneficiaries of agglomeration economies) should be done by themselves based on Polluter-Pay-Principle regulated by local government, while (ii) the cost of household wastes should be done as a public service provided by municipality or local authority.

The MSWM service needs various infrastructure, facilities, equipment and human resources: (1) Waste Collection (Containers, Trucks), (2) Waste Transportation (Trucks, Transfer Station), (3) Intermediate Treatment (Treatment Facility, Equipment), (4) Final Disposal (Disposal facility), and (5) Administration Office (see Figure 2).
The initial cost for these facilities and equipment are often absorbed by subsidies or grant from government or external donors, local government bond, or private finance initiative (PFI). In developing countries, a number of official development assistance (ODA) projects have supported this type initial cost investment program.

On the other hand, the operation and maintenance $(\mathrm{O} / \mathrm{M})$ cost for implementation of MSWM using these facilities and equipment is generally managed by themselves as expenditures from local government finance (common account and/or public enterprise account). Budget for MSWM service activities often represent a significant proportion of the total municipal budget in cities of developing countries. In addition to the local government budget, waste collection fee, tipping fee, or environmentally related tax [19] are used to be collected from residents, which sometimes cover significant part of total $\mathrm{O} / \mathrm{M}$ cost. The tariff is sometimes specific to discharged waste amount, property tax rate, or utilities (water, electricity) charge. The specific tariff is especially applicable to urban area, because the costs for urban MSWM have to be incurred by the profits of agglomeration economies.

Although MSWM service is generally responsibility of local authorities, a sound alliance between the municipality and the private enterprise, public-private partnership (PPP), is crucial to develop and implement appropriate solutions that lead to an enhanced financial sustainability of the SWM system in developing countries. Both initial cost and $\mathrm{O} / \mathrm{M}$ cost can be supported using PPP [20] under licensing, monitoring, and control by public authority.

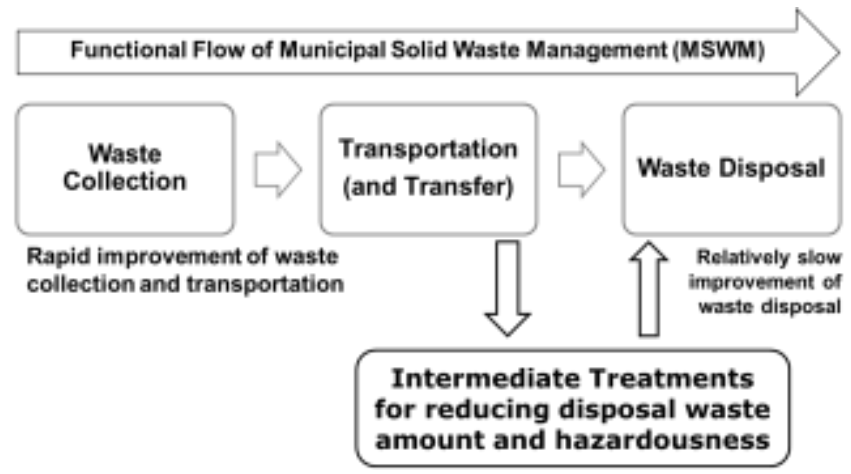

Figure 2: Typical MSWM system and management flow. Four management units, Collection, Transportation, Intermediate Treatment, and Disposal, need facility and equipment with human resources. 
Proc. of The Fifth Intl. Conf. On Advances in Applied Science and Environmental Technology - ASET 2016 Copyright (C) Institute of Research Engineers and Doctors, USA .All rights reserved.

ISBN: 978-1-63248-106-1 doi: 10.15224/ 978-1-63248-106-1-34

\section{Informal Sector}

According to the definition given by World Bank, the informal sector is divided into two groups having different nature: (i) the informal sector is formed by the coping behavior of individuals and families in economic environment where earning opportunities are scarce; (ii) the informal sector is a product of rational behavior of entrepreneurs that desire to escape state regulations. In the case of informal sector engaging MSWM related activities in developing countries, both (i) and (ii) groups can be observed.

The informal sector having the nature (i) is composed of waste pickers and labors working for informal recycling industries. The waste pickers are mostly socially vulnerable but they actually contribute to waste reduction and material recycling in the MSWM.

In contrary, the informal sector having the nature (ii) consists of informal dealers of recyclables, junk shops, and recycling industries. They basically correspond to the beneficiary of agglomeration economies in the urban areas without licensing and tax payment. They seek to reduce costs related to wages and other social costs including MSWM costs. It is necessary to recognize their activities and internalize them into formal recycling industries, which contributes to enhance MSWM system performance.

Informal sector is observed not only in MSWM but in other business which sometimes large portion of economy, which is potentially a free rider of MSWM service.

\section{Role of Public Administration}

"Waste is like a mirror that reflects various aspects of a society." [21] [22]. In fact if a city is dirty, the local administration may be considered ineffective or public awareness of residents and community is insufficient.

An effective and transparent institutional framework is essential for good governance in MSWM. Without such a framework, the MSWM will not function and no sustainability. In addition, a municipality must have the capacity and the organizational structure to manage finances and services in an efficient and transparent manner. Clear budgets and lines of accountability are essential [2].

In order to establish effective and efficient SWM in urban areas, major three systems; economic system, social system, and public administration system, are properly liked and coordinated [23]. The economic system generates economic profit under the agglomeration economies, and at the same time it is major waste generators. The social system provides, and protects, the urban environment for people. The public administration system has to collect the cost for treatment of generated waste from the economic system and deliver public service of waste management for the social system. Under the mechanism of PPP, the public administration system is expected to control the private MSWM service activities through licensing, outsourcing, cooperation, and monitoring (see Figure 3). For the further development of the relationship among three systems, economic instruments - unit pricing, deposit-refunds, product charges, recycling subsidies, and taxes on primary product inputs [24] - are important tools.

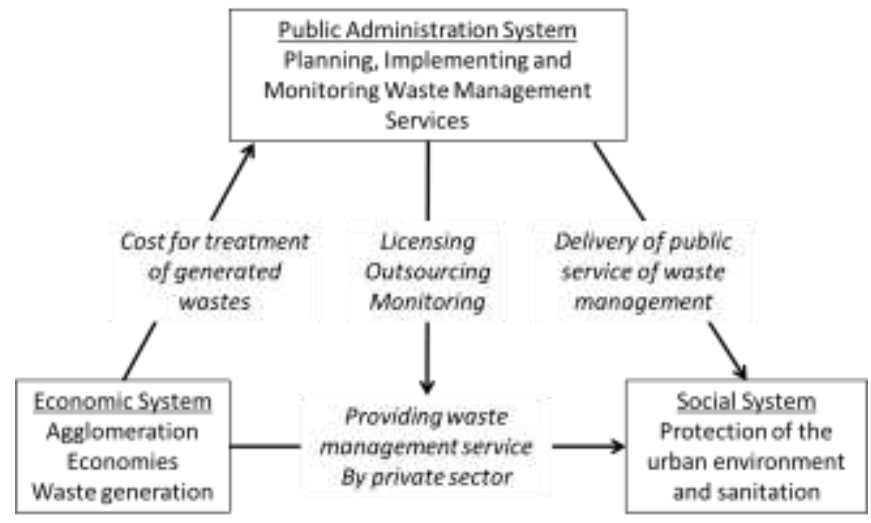

Figure 3: Relationship among Economic system, Public administration system, and Social system regarding MSWM (modified from [23]).

Thus, well-balanced relationship among economic system, social system, and public administration system, is essential, which can be realized through capacity development (CD; [22]) in MSWM.

\section{Iv. Framework of Capacity Development Support}

In order to promote sustainable MSWM, the CD support or technical assistance by external donor is expected. As mentioned previously, MSWM encompasses numerous factors particularly in urban areas. Challenge of CD support in MSWM is also widely diversified. So far, several CD support frameworks in solid waste management sector have been proposed by donor agencies (e.g., [22] [1] [25] [26]).

There are three categories of $\mathrm{CD}$ support subjects as shown in Figure 3: Category 1 (Support Subjects - Group 1) corresponds to capacity enhancement at social and institutional level; Category 2 (Support Subject - Group 2) to capacity enhancement at organizational (public administration) and managerial level; and Category 3 (Support Subjects - Group 3) to capacity enhancement at technical and technological level (Figure 4).

The Support Subject Group 1 covers social and institutional issues which are the enabling environment and conditions for MSWM. It consists of six support subjects; background survey of socio political economy, promotion of institution building, promotion of public awareness, strengthening environmental education, promotion of public-private partnership including micro-finance and financial inclusion [28], and internalization of informal sector. The support subject "public awareness" is subdivided into four specific subjects; public awareness raising, promotion of willingness-to-pay of waste related fee/tax, consensus-building on siting of SWM facilities, and participation of citizens to MSWM activities such as community-based SWM. The Group 1 is the background of solid waste management and closely related to the subjects of economic system and social system shown in Figure 3, without which the public service activity of solid waste management is not functional. 
Proc. of The Fifth Intl. Conf. On Advances in Applied Science and Environmental Technology - ASET 2016 Copyright (C) Institute of Research Engineers and Doctors, USA .All rights reserved.

ISBN: 978-1-63248-106-1 doi: 10.15224/ 978-1-63248-106-1-34

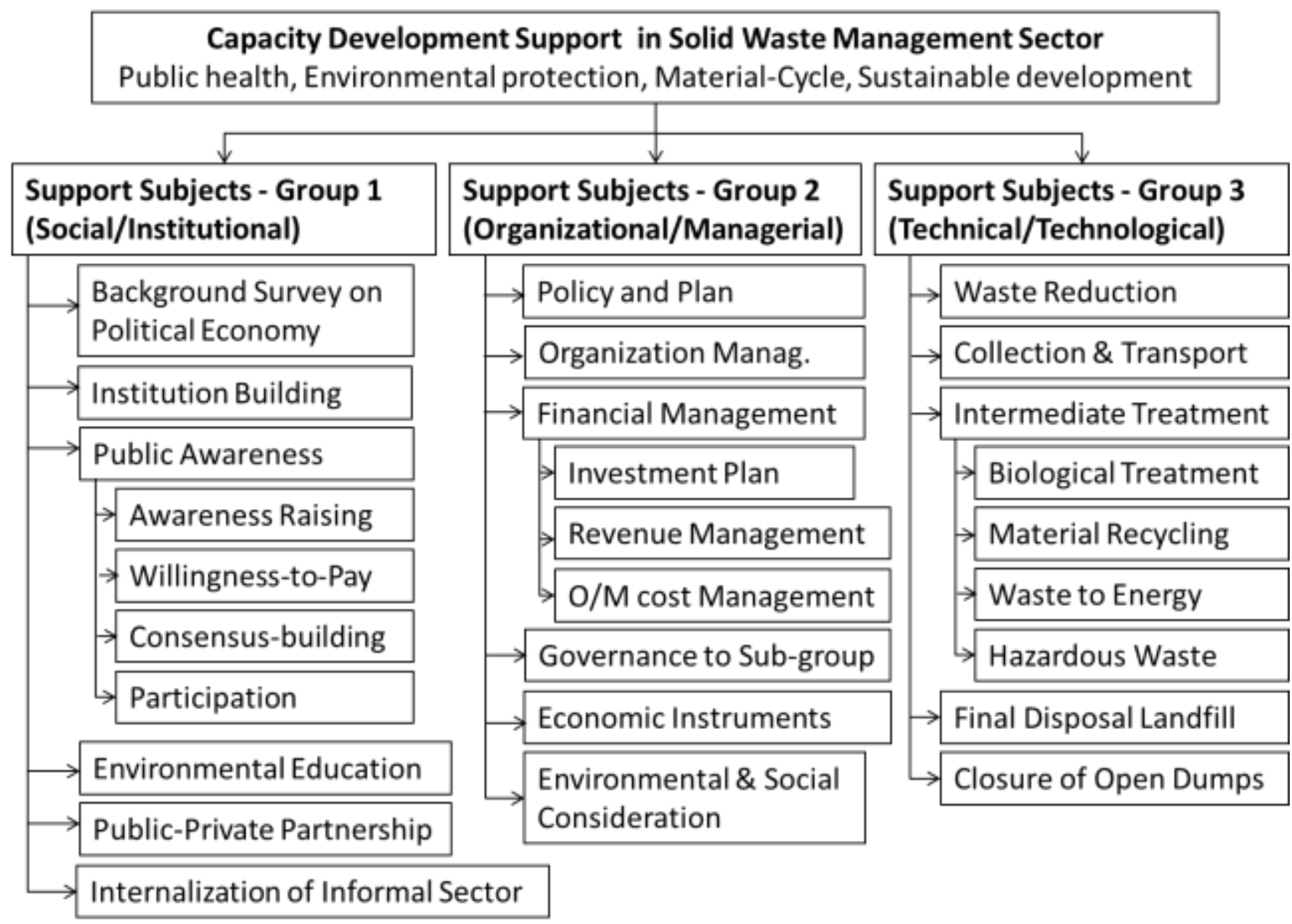

Figure 4: Proposed framework for capacity development (CD) supports in SWM sector. Actual CD support program is prepared based on the results of capacity assessment [30].

The Support Subjects Group 2 relates organizational issues of MSWM implementing agency. The Category 2 consists of six support subjects; formulation of policy and plan, strengthening organizational management, strengthening financial management, governance to subgroup (e.g., guidance and support to local government from central government), promotion of economic instruments for participation and public-private partnership, and strengthening environmental \& social consideration (e.g., environmental assessment). The support subject "financial management" is subdivided into three specific subjects; preparation of investment plan, strengthening revenue management, and strengthening $\mathrm{O} / \mathrm{M}$ cost management and cost recovery. The Group 2 is closely related to the challenges of public administration system shown in Figure 3.

The Support Subjects Group 3 includes technical and technological issues in SWM. They are frequently discussed as elements of solid waste management system [27]. It contains five support subjects; waste reduction techniques (such as source separation, home-composting etc.), improvement of collection \& transport, introduction of intermediate technologies, improvement of final disposal landfill, and safety closure of open dumpsite. The support subject "intermediate treatment" includes four specific subjects; biological treatment, material recycling, waste-toenergy, and hazardous waste treatment.
These three Groups of Support Subjects are interrelated and mutually play the causes and effects. According to the development level of SWM the priority issues should be changed [29]. It is not necessary for donor to support all subjects, but the support subject(s) should be selected based on the capacity assessment [30] as well as policy direction on MSWM given by the urban city authority.

\section{Acknowledgment}

The author thanks the colleagues in Japan International Cooperation Agency (JICA) and its counterparts in developing countries who engaged various JICA projects for capacity development in solid waste management. The views expressed in this paper is author's one and not necessarily reflect JICA's position.

\section{References}

[1] UN-HABITAT (2010) Solid Waste Management in the World's Cities- Water and Sanitation in the World's Cities 2010. Earthscan

[2] ISWA (2010) Solid Waste: guideline for successful planning. International Sold waste Association.

[3] UN-HABITAT (2016) Urbanization and Development Emerging Futures: World City Report 2016. United Nations Human Settlements Programme (UN-Habitat). 
Proc. of The Fifth Intl. Conf. On Advances in Applied Science and Environmental Technology - ASET 2016 Copyright (C) Institute of Research Engineers and Doctors, USA .All rights reserved.

ISBN: 978-1-63248-106-1 doi: 10.15224/ 978-1-63248-106-1-34

[4] Bloom, D. E., Canning, D., and Fink, G. (2008) Urbanization and the wealth of nations. Program on the Global Demography of Aging (PGDA) Working Paper No. 30, Harvard Institute of Global Health.

[5] Iimi, A. (2004) Urbanization and Infrastructure Development in East Asia. Journal of JBIC Institute, 20, pp. 4-25. (in Japanese)

[6] Henderson, V. (2003) The Urbanization Process and Economic Growth: The So-What Question. Journal of Economic Growth, 8 (1), pp 47-71.

[7] World Bank (2000) World Development Report 1999/2000: Entering the 21st Century. The World Bank, Oxford University Press.

[8] Asian Development Bank (1999) Urban Sector Strategy. ADB Policy Paper, Asian Development Bank. http://www.adb.org/sites/default/files/institutionaldocument/32051/urbansector.pdf

[9] Harris, J. R. \& Todaro, M. P. (1970), Migration, Unemployment and Development: A Two-Sector Analysis. American Economic Review, 60 (1): pp.126-142.

[10] Brueckner, J. K. (2011) Lectures on Urban Economics. MIT Press.

[11] Gaeser, E. L. (ed.2010) Agglomeration Economics. The University of Chicago Press.

[12] Fay, M. and Opal, C. (1999) Urbanization without growth: A not-so-uncommon phenomenon. The World Bank Policy Research Working Paper, No.2412.

[13] African Development Bank (2013) Recognizing Africa's Informal Sector. http://www.afdb.org/en/blogs/ afdb-championing-inclusive-growth-across-

africa/post/recognizing-africas-informal-sector-11645/

[14] Ostrom, E. (1990) Governing the Commons - The evolution of institutions for collective action. Cambridge University Press

[15] Gries, T and Grundmann, R. (2015) Fertility and modernization: The role of urbanization in developing countries. Journal of International Development, DOI: 10.1002/jid.3104

[16] Miyamoto, K. (1999) Thought and Reality of Urban Policy. Yuhikaku Publishing. (in Japanese)

[17] Ostrom, E., Gardner, R. and Walker, J. (1994) Rules, Games, and Common-Pool Resources. The University of Michigan Press.

[18] Schübeler, P., Wehrle, K. and Christen, J. (1996) Conceptual framework for municipal solid waste management in low-income countries. Urban Management Program (UMP) Working Paper No. 9, Swiss Agency for Development and Cooperation (SDC).
[19] OECD (2007) The Political Economy of Environmentally Related Taxes. OECD Policy Brief, February 2007, Organization for Economic Co-operation and Development.

[20] Lohri, C. R., Camenzind, E. J. and Zurbrügg, C. (2014) Financial sustainability in municipal solid waste management - Costs and revenues in Bahir Dar, Ethiopia. Waste Management, 34, pp. 542-552.

[21] Sakurai, K. (2000) Municipal Solid Waste Management in Developing Countries: Towards more Efficient International Cooperation in Municipal Solid Waste Management Sector. Journal of Japan Society of Waste Management Experts (Haikibutsu gakkai shi), 11 (2), pp.142-151. (in Japanese with English abstract)

[22] JICA (2005) Supporting Capacity Development in Solid Waste Management in Developing Countries Towards Improving Solid Waste Management Capacity of Entire Societies-, Institute for International Cooperation, Japan International Cooperation Agency.

[23] Yatsuki, S. (2004) Administration and Finance System for Waste Management. Yuhikaku Publishing, Tokyo. (in Japanese)

[24] Turner,R. K., Powell,J. and Craighill,A. (1996) Green taxes, waste management and political economy. CSERGE Working Paper, WM 96-03, Centre for Social and Economic Research on the Global Environment, University of East Anglia and University College London.

[25] JICA (2010) Position Paper on Supports in Solid Waste Management. Global Environment Department, JICA.

[26] Yoshida, M. (2012) Development of inclusive and dynamic solid waste management - Challenge for international technical cooperation with developing countries-. Urban Cleansing (Toshi Seiso), 65, pp.439-444. (in Japanese)

[27] Eriksson, O., Reich M. C., Frostell, B., Bjorklund, A., Assefa, G., Sundqvist, J.-O., Granath J., Baky, A., Thyselius, L. (2005) Municipal solid waste management from a systems perspective. Journal of Cleaner Production, 13, pp.241-252.

[28] Nugent, R. (2002) Microcredit, social capital, and common pool resources. World Development, 30 (1), pp.95105.

[29] Yoshida, M. (2011) Phased development of municipal solid waste management and needs for international technical assistance in developing countries. Proceedings of 2011 World Congress of International Solid Waste Association (ISWA), p.485-495.

[30] JICA (2008) Capacity Assessment Handbook - Project Management for Realizing Capacity Development. JICA Research Institute. 